\title{
The growth hormone-insulin-like growth factor-I axis in the diagnosis and treatment of growth disorders
}

\author{
Werner F Blum ${ }^{1}$, Abdullah Alherbish², Afaf Alsagheir ${ }^{3}$, Ahmed El Awwa4, Walid Kaplan5, Ekaterina Koledova6 \\ and Martin O Savage ${ }^{7}$
}

${ }^{1}$ University Children's Hospital, Giessen, Germany

${ }^{2}$ Al Habib Medical Group, Riyadh, Saudi Arabia

${ }^{3}$ King Faisal Specialist Hospital and Research Center, Riyadh, Saudi Arabia

${ }^{4}$ Department of Pediatric Endocrinology \& Diabetes, Hamad Medical Center, Doha, Qatar

${ }^{5}$ Tawam Hospital, Al Ain, UAE

${ }^{6}$ Global Medical Affairs Endocrinology, Merck KGaA, Darmstadt, Germany

${ }^{7}$ William Harvey Research Institute, Barts and the London School of Medicine \& Dentistry, London, UK

Correspondence should be addressed to M O Savage: m.o.savage@qmul.ac.uk

\begin{abstract}
The growth hormone (GH)-insulin-like growth factor (IGF)-I axis is a key endocrine mechanism regulating linear growth in children. While paediatricians have a good knowledge of GH secretion and assessment, understanding and use of measurements of the components of the IGF system are less current in clinical practice. The physiological function of this axis is to increase the anabolic cellular processes of protein synthesis and mitosis, and reduction of apoptosis, with each being regulated in the appropriate target tissue. Measurement of serum IGF-I and IGF-binding protein (IGFBP)-3 concentrations can complement assessment of GH status in the investigation of short stature and contribute to prediction of growth response during GH therapy. IGF-I monitoring during GH therapy also informs the clinician about adherence and provides a safety reference to avoid over-dosing during long-term management.
\end{abstract}

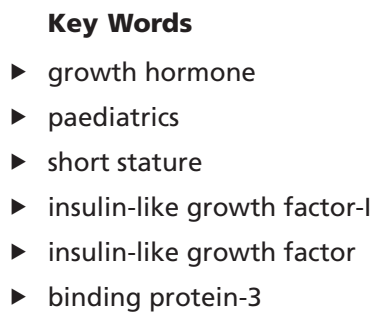

\section{Introduction}

The growth hormone (GH)-insulin-like growth factor (IGF)-I axis is the principle endocrine system regulating linear growth in children (1). Linked to the nutritional status of the individual, GH is a potent stimulator of IGF-I secretion and action. Recombinant human GH (rhGH) administration to children with GH deficiency is effective at promoting growth, and may also enhance height gain in a number of non-GH deficiency disorders (2). Although knowledge of GH secretion and the clinical techniques for assessing GH production are generally well known by practising paediatric endocrinologists, awareness of the physiology of the IGF system and its use in clinical management is less current.

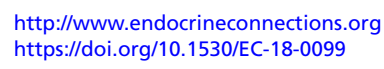

RhGH has been available for clinical use since 1985, when the global Creutzfeldt-Jakob epidemic, related to the use of pituitary-derived hGH, precipitated its licensing by the US Food and Drug Administration and European Medicines Agency. However, rhGH therapy has evolved in the past 30 years. Originally administered intramuscularly three times weekly, it is now given daily by subcutaneous injection.

A number of long-acting GH preparations are currently in various phases of clinical studies $(3,4)$. Several different techniques have been used in their development, such as modification of the $\mathrm{GH}$ molecule by protein enlargement or albumin binding, which results in GH analogues with

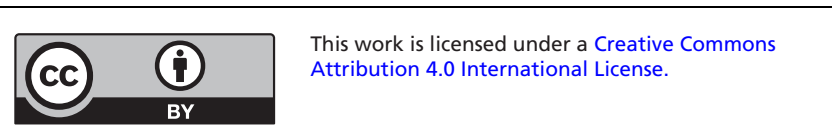


longer half-lives. Transient binding of GH to polyethylene glycol, so-called pegylation, and use of depot technologies also result in prolonged biological activity. It is likely that weekly or fortnightly GH injections will have an impact on clinical practice in the next 5 years $(3,4)$.

Understanding of the range of $\mathrm{GH}$ responsiveness in GH deficiency, and particularly in non-GH deficiency disorders such as Turner syndrome, short stature related to birth size small for gestational age (SGA) and idiopathic short stature (5), has led to development of prediction models of growth response (6) and a recognition that GH therapy needs to be tailored to each child, depending on their diagnosis and individual characteristics.

Consideration of the IGF system, its contribution to the initiation of GH therapy and the assessment of its effectiveness, has been somewhat neglected. With the aims of studying the GH-IGF-I axis and specifically the use of circulating concentrations of serum IGF-I and IGFbinding protein (IGFBP)-3 in clinical management, an Advisory Board was convened in Dubai in December 2016, by Merck KGaA, Darmstadt, Germany, to address these issues. This article reports the discussions and conclusions of the Advisory Board meeting.

\section{Physiology of GH-IGF-I axis}

\section{Regulation of GH secretion and targets for GH action}

From the age of 1 year onwards, the GH-IGF-I axis is a key regulator of linear growth. Growth hormone is a 191 amino acid protein, with a molecular weight of $22 \mathrm{kDa}$, produced and secreted in a pulsatile fashion from the anterior pituitary gland (7) under positive control of $\mathrm{GH}$ releasing hormone (GHRH) and negative control of somatostatin. Both GHRH and somatostatin are secreted by the hypothalamus. The main targets for GH action are the liver, where it induces the release of both glucose and IGF-I, and adipose tissue, where it controls the release of fatty acids (8). There is also a direct effect on cartilage cells in the growth plates of the long bones, which also secrete IGF-I to act locally (9).

\section{Components of the IGF system}

There are numerous components involved in the IGF system. IGF-I itself is a small protein consisting of 70 amino acids, with a molecular weight of $7.65 \mathrm{kDa}$, and the gene is located at chromosome 12q23 (10). IGF-I in the circulation is predominantly produced by hepatocyte cells in the liver, although it is also secreted by many other cells in the body. IGF-I is bound to specific IGFBPs in the circulatory system, and six IGFBPs have been identified (11). The production of IGFBP-1 and -2 is inhibited by GH whereas production of IGFBP-3, -4 and -5 is stimulated by GH (Fig. 1). IGFBP-3 is produced by the hepatic sinusoidal cells, at the junction of the intravascular space. In the circulation, IGF-I is mainly bound to IGFBP-3 and this binary complex then binds to a large protein called the acid-labile subunit (ALS) to form a ternary complex (1) (Fig. 2). The ternary complex inactivates both IGF-I and IGFBP-3 and prolongs their half-life in the circulation. While IGF-I is bound to IGFBP-3 it is not active, but can be released through chemical equilibrium or proteolysis in peripheral tissues, and free IGF-I then binds to cell surface receptors to trigger a signalling cascade within the cell. However, IGFBP-3 can also act as a hormone, binding either to a specific receptor or to importin-beta at the cell surface. It is then translocated to the cell nucleus where it interacts with the retinoid $\mathrm{X}$ receptor and nuclear receptor 77 to form a complex that can regulate transcription and can induce apoptosis $(12,13)$ (Fig. 3).

\section{Factors influencing serum IGF-I and IGFBP-3 concentrations}

$\mathrm{GH}$ is the major stimulator of IGF-I and IGFBP-3 secretion from the liver and levels are decreased by liver failure, returning to normal following restoration of hepatic function (14). However, GH is not the only factor controlling IGF-I concentration in the circulation (Table 1). Insulin (15), thyroid hormone (16) and androgens (17) all stimulate IGF-I release, and oestrogens at low levels stimulate and at high doses inhibit secretion (17). Malnutrition also has a strong inhibitory effect on IGF-I, IGFBP-3 and ALS (18), and serum concentrations are reduced by conditions that affect nutrition, such as coeliac disease (19) and anorexia (20). Malnutrition may act at least partially through an increase in fibroblast growth factor 21, which suppresses GH action and also increases serum IGFBP-1 concentration $(18,21)$.

Chronic inflammation, as seen for example in Crohn's disease or juvenile chronic arthritis can disturb the physiological synergy of GH and IGF-I, known as the dual-effector theory. This is based on the principle that $\mathrm{GH}$ regulates the expression of locally produced IGF-I, which then acts in an autocrine/paracrine manner. Proinflammatory cytokines, such as TNF-alpha, interfere both with circulating IGF-I production resulting in hepatic GH resistance (22) and with the action of locally produced http://www.endocrineconnections.org https://doi.org/10.1530/EC-18-0099 (c) 2018 The authors Published by Bioscientifica Ltd
This work is licensed under a Creative Commons Attribution 4.0 International License. 
Hypothalamus

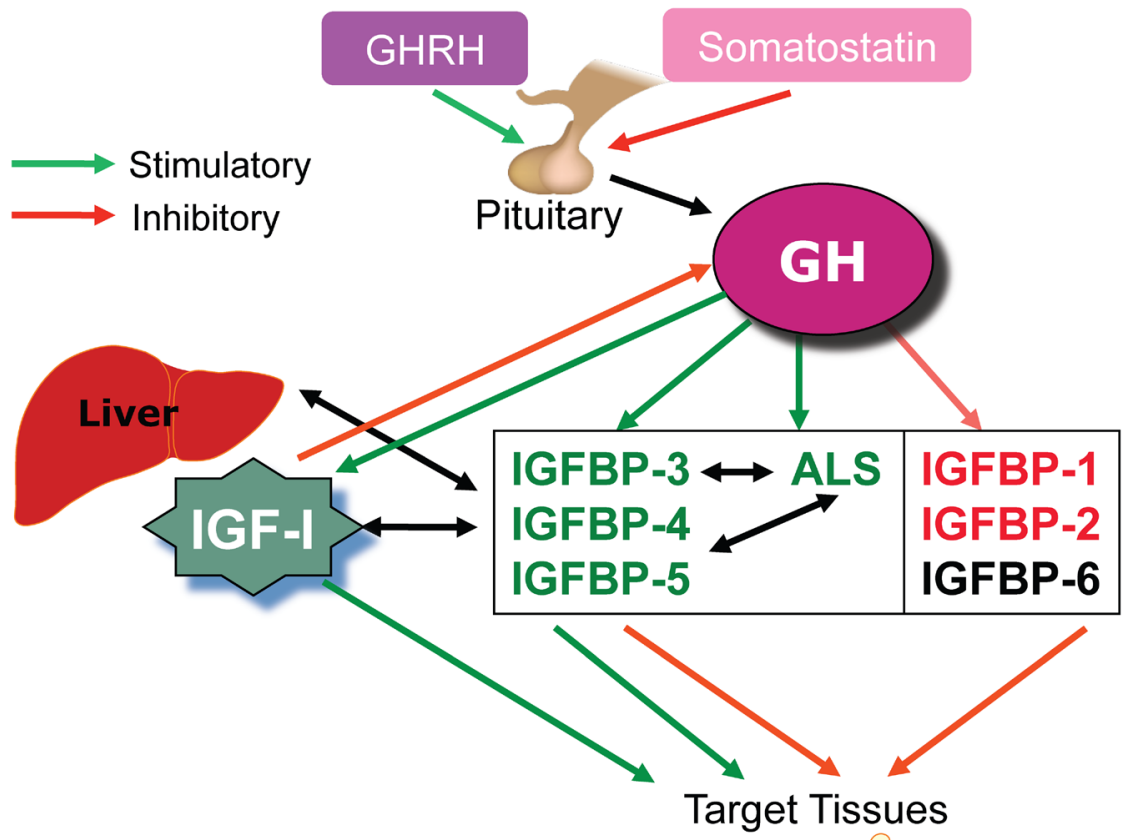

IGF-I by decreasing proliferation and differentiation of chondrocytes in the growth plate (23).

\section{GH and IGF-I actions on linear growth}

The original somatomedin hypothesis proposed that GH did not have any direct effects, but exerted its action to

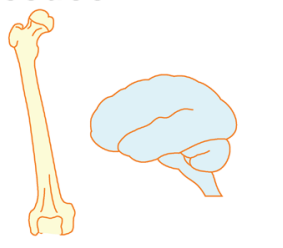

Figure 1

The complex influence of GH through the IGF system. GH, growth hormone; GHRH, GH releasing hormone; IGF, insulin-like growth factor; IGFBP, IGF-binding protein.

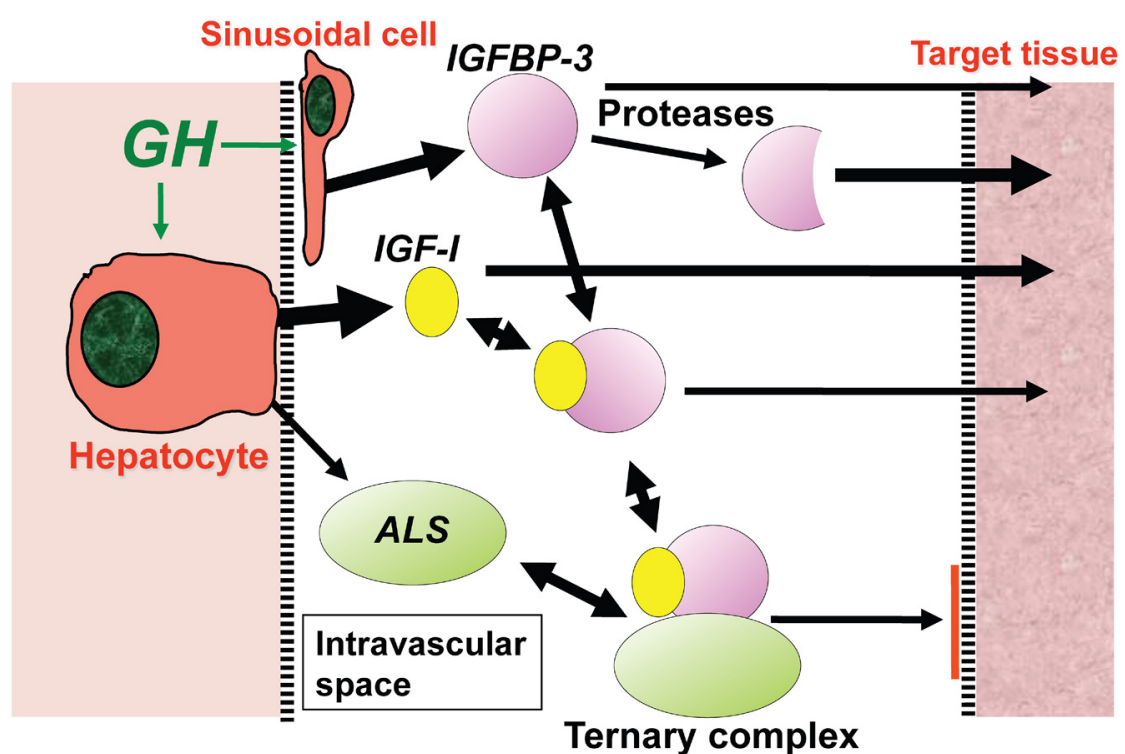

Ternary complex induce bone growth entirely through IGF-I, then known as somatomedin-C (24). However, the 'dual effector hypothesis' in 1985 suggested that GH could also act directly to promote differentiation of cells (25). Studies also showed that IGFs are expressed in most tissues and GH regulates locally produced IGF-I, which then acts in an autocrine/paracrine manner; thus, GH and IGFs have
Figure 2

Influence of GH on the generation of IGF-I and IGFBP-3 from the liver into the intravascular space. Interaction of IGF-I with proteases, IGFBP-3 and ALS. ALS, acid labile subunit; $G H$, growth hormone; IGF, insulin-like growth factor; IGFBP, IGF-binding protein. http://www.endocrineconnections.org https://doi.org/10.1530/EC-18-0099 (c) 2018 The authors Published by Bioscientifica Ltd

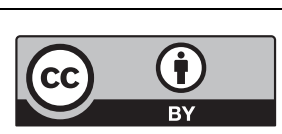

This work is licensed under a Creative Commons Attribution 4.0 International License. 


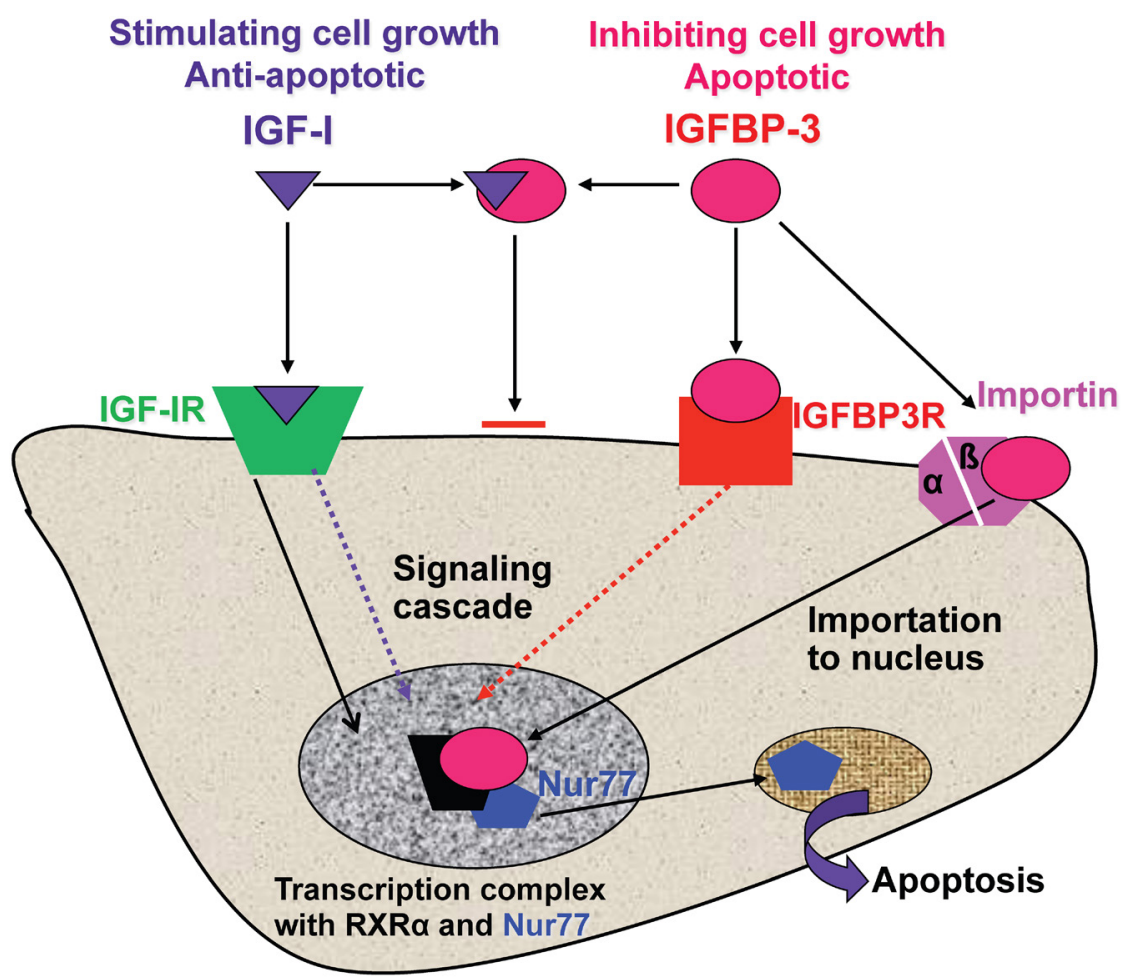

Figure 3

Actions of IGF-I and IGFBP-3 in regulating gene transcription and control of apoptosis. IGF, insulin-like growth factor; IGFBP, IGF-binding protein. complex interconnected direct and indirect actions on the growth plate (10). In the body as a whole, GH and IGF-I appear to have opposite effects on carbohydrate metabolism, whereas lipid metabolism is only affected by GH. Thus, GH causes release of nutrients from stores and IGF-I responds and acts in the tissues where nutrients are needed.

\section{Growth plate physiology}

Bone growth is regulated by a complex network of signals (9). Both GH and IGF-I form part of this network and are able to promote chondrocyte proliferation and differentiation. The cartilage growth plates consist of three main layers known as the resting zone, proliferative zone and the hypertrophic zone, although chondrocytes are the only cell type and each layer is segregated by the rates of proliferation and differentiation within them $(9,26)$ (Fig. 4). In the resting zone GH is thought to act to induce the chondrocytes, which act like stem cells, to differentiate and proliferate (27). IGF-I acts predominantly at the proliferative and hypertrophic zones to further induce differentiation and increase in height within columns of cells that then calcify the surrounding matrix $(26,28)$.

http://www.endocrineconnections.org

https://doi.org/10.1530/EC-18-0099

() 2018 The author Published by Bioscientifica Ltd

\section{Regulation of pre- and postnatal growth}

GH appears to primarily affect postnatal growth and GH deficiency or GH resistance does not significantly affect birth length, weight or BMI (29). In contrast, IGF-I affects both pre-natal and postnatal growth, and defects of IGF-I secretion and action are associated with intrauterine growth retardation and birth size SGA $(30,31)$. Studies in mice showed that specifically knocking-out liver production of IGF-I resulted in intrauterine growth retardation, but postnatal growth was normal. This was possibly due to GH inducing local production of IGF-I and binding proteins then maintaining a serum pool of IGF-I (8).

\section{Contributions of circulating vs peripherally secreted IGF-}

Additional knockout of the IGFALS gene inhibited linear growth indicating that serum IGF-I, not just locally produced IGF-I, is important to maintain bone growth (32) and deficiency of ALS in children is associated with growth retardation $(33,34,35)$. Mice deficient in liverspecific IGF-I also had a large increase in serum GH, which could have contributed to maintain postnatal growth (36). Thus, GH and IGF-I appear to act synergistically, 
Table 1 Hormonal regulators of circulating IGF-I and IGFBP-3 concentrations.

\begin{tabular}{|c|c|}
\hline Hormone & Effect \\
\hline Growth hormone & $\uparrow \uparrow \uparrow$ \\
\hline Prolactin & $\uparrow ?$ \\
\hline Insulin & $\uparrow$ \\
\hline Thyroid hormones & $\uparrow$ \\
\hline Glucocorticoids & $\uparrow$ \\
\hline Androgens & $\uparrow$ \\
\hline Oestrogens & Low dose $\uparrow$, high dose $\downarrow$ \\
\hline
\end{tabular}

Gonadotropins, thyroid stimulating hormone, adrenocorticotrophic hormone and parathyroid hormone stimulate local production of IGF-I in their respective target tissues.

IGF, insulin-like growth factor; IGFBP, IGF-binding protein.

with both involved in bone growth and remodelling, to influence longitudinal growth and bone strength.

\section{Key steps in the investigation of short stature}

\section{Clinical assessment}

For paediatric patients with growth retardation, investigation should begin with clinical assessment that includes family history, medical history, phenotype examination, pubertal stage, measurement of body proportions and assessment for any dysmorphic features $(37,38,39,40,41,42)$. Mid-parental height and any available height and weight measurements should be plotted on appropriate charts; World Health Organisation (WHO) charts being frequently used (43), but countryspecific charts are preferable because WHO charts are designed for multi-ethnic populations (44).

\section{Laboratory assessment}

\section{General investigations}

If the medical history and physical examination do not indicate a specific diagnosis, laboratory tests should be carried out $(41,45)$, which should include assessments for coeliac disease, Crohn's disease and determination of karyotype for girls with unexplained short stature and short boys with associated genital abnormalities. While coeliac disease may be considered an uncommon cause of growth retardation, rates of up to $15 \%$ of children with short stature have been reported $(46,47)$ and diagnosis is often delayed (48). Inflammation in children with Crohn's disease is associated with reduced growth, even after adjustment for steroid use (49). Diagnosis of Turner syndrome in girls with short stature may also be delayed without karyotyping and this may adversely influence morbidity and mortality (50), as well as effectiveness of $\mathrm{GH}$ treatment $(51,52)$. Testing for SHOX gene abnormalities should also be considered when the phenotype or family history is suggestive of this genetic defect $(37,53)$.

\section{Endocrine investigations}

If no specific diagnosis is identified from general paediatric investigations, the GH-IGF axis should be assessed, starting with measurement of IGF-I and IGFBP-3 concentrations (41). GH stimulation tests should be performed in patients with a medical or familial history and physical examination that is compatible with GH deficiency. However, GH stimulation testing may not be required for patients with hypothalamic-pituitary defects and at least one other pituitary hormone deficiency, where GH

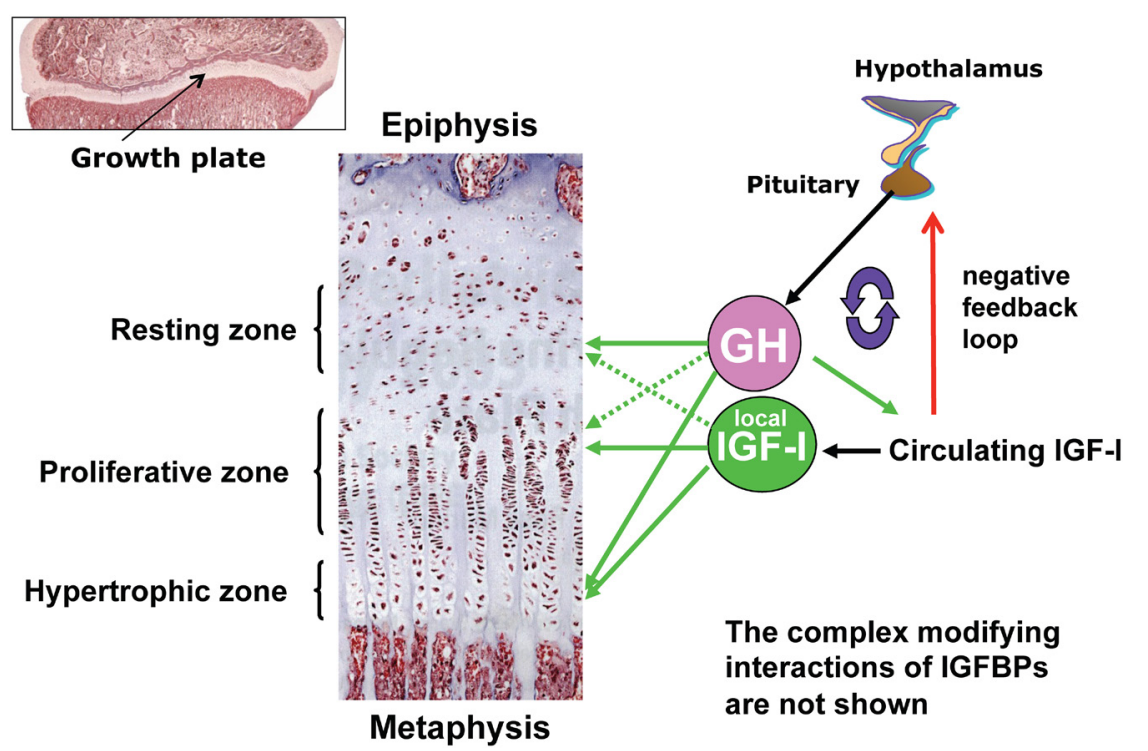

Figure 4

Chondrocyte differentiation, proliferation, hypertrophy and ossification at the growth plate. Reproduced, with permission, from Nilsonn O, Marino R, De Luca F, Phillip M, Baron J. Endocrine regulation of the growth plate. Hormone Research 200564 157-165 (26). Copyright 2005 Karger Publishers, Basel, Switzerland. GH, growth hormone; IGF, insulin-like growth factor; IGFBP, IGF-binding protein. http://www.endocrineconnections.org https://doi.org/10.1530/EC-18-0099 (c) 2018 The authors Published by Bioscientifica Ltd

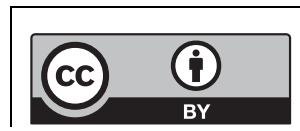

This work is licensed under a Creative Commons Attribution 4.0 International License. 
deficiency may be assumed (37). A GH stimulation test is also not required for short children with a normal height velocity, no bone age delay and serum IGF-I level at or above the mean for age and gender (5). A peak stimulated $\mathrm{GH}$ concentration of $<7 \mu \mathrm{g} / \mathrm{L}$ is generally considered to be consistent with GH deficiency (37), however definitions vary from country to country and the biochemical cutoff, e.g. $<7$ or $<10 \mu \mathrm{g} / \mathrm{L}$, should always be supported by auxological evidence of subnornal growth velocity.

The GH stimulation tests currently recommended for paediatric patients include glucagon, clonidine, arginine or GHRH plus arginine. Interpretation of peak GH concentration should take account of day-to-day variation and impact of nutritional status, age and pubertal development $(37,54)$. Sex steroid priming is recommended before GH stimulation in children who are just pre-pubertal and with age greater than 10 years in girls and greater than 11 years in boys (37). The peak GH concentration used to define GH deficiency varies by country, by clinical centre and by assay used, and GH assays should use an established international standard (55). Clinicians need to be aware of the assay used in their laboratory and how these factors may affect the response $(56,57,58)$.

\section{Measurement of IGF-I and IGFBP-3 concentrations}

IGF-I and IGFBP-3 concentrations can be measured in either serum or plasma samples, but for comparison between patients the same medium should be used to avoid variation; in either case, separation from whole blood should be carried out within $2 \mathrm{~h}$ and samples can then be frozen, where determinations remain constant over periods of several years (59). IGF-I and IGFBP-3 concentrations are most frequently measured using immunoassays (60).
Commercially available IGF-I assays, as used in most hospital laboratories, rely on binding of the IGF-I to an antibody, and the antibodies used differ in their ability to bind to IGF-I resulting in substantive variations between assays (55). The antibody should be very specific, with high affinity for IGF-I and minimal cross-reactivity with IGF-II. IGFBPs interfere in the binding of IGF-I antibody $(61,62,63)$. To overcome this, serum samples are acidified and an excess of IGF-II is added, with neutralisation of the solution. The IGFBP binding site is blocked by IGF-II, leaving the IGF-I free to bind to the antibody. A number of immunoassays for measurement of IGFBP-3 are commercially available $(60,61,64,65)$; these are unaffected by presence of IGF-I and do not require an acidification step.

Serum concentrations of IGF-I and IGFBP-3 show little circadian variation, so measurements can be made from a single sample taken at any time throughout the day. Assays may vary widely in the results for absolute concentration and, therefore, comparing values measured with different assays requires caution. Attempts have been made to cross-calibrate different assay kits for IGF-I and IGFBP-3, which allows conversion of results to make them comparable $(66,67,68)$. However, even using the same assay, age, sex and pubertal stage all influence IGF-I and IGFBP-3 concentrations (Fig. 5). Therefore, values from a large reference population are necessary to provide meaningful evaluation of an individual patient against normative data $(59,61,65,68,69)$. These reference population values can then be used to convert absolute concentrations of IGF-I and IGFBP-3 into SDS $(61,65)$. Methods for calculating age and sex-based SDS have been described $(61,68)$, and computer software programs have been developed to enable these calculations to be carried out quickly and easily. Normal values for IGF-I
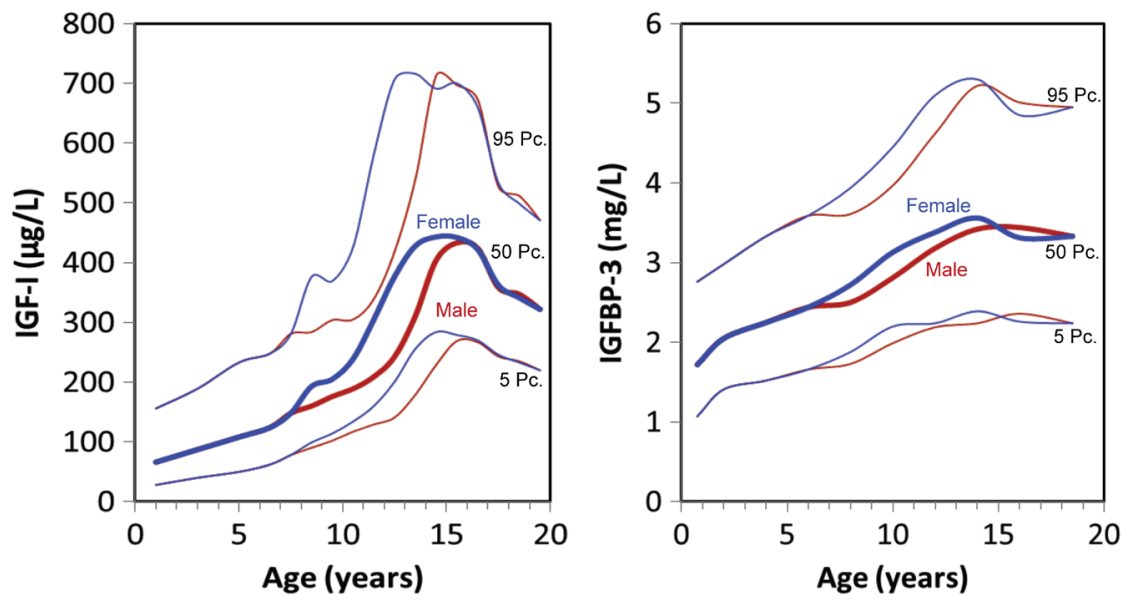

\section{Figure 5}

Normal ranges of serum IGF-I and IGFBP-3 in children and interpretation of serum IGF-I and IGFBP-3 levels. Drawn from data reported in Blum WF, Böttcher C, Wudy SA. Insulin-like growth factors and their binding proteins. In: Diagnostics of Endocrine Function in Children and Adolescents, ed. 4, pp 157-182. Eds Ranke MB, Mullis P-E. S Karger, Basel, 2011 (61). IGF, insulin-like growth factor; IGFBP, IGF-binding protein.

$$
\begin{aligned}
& \text { http://www.endocrineconnections.org } \\
& \begin{array}{l}
\text { https://doi.org/10.1530/EC-18-0099 } 2018 \text { The authors } \\
\text { Published by Bioscientifica Ltd }
\end{array}
\end{aligned}
$$

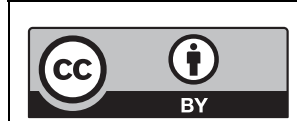

This work is licensed under a Creative Commons Attribution 4.0 International License. 
SDS and IGFBP-3 SDS range from -2 to +2 , with the 50th percentile as 0 .

\section{Interpretation of IGF-I and IGFBP-3 concentrations}

Decreased serum IGF-I SDS is associated with a variety of clinical conditions, in addition to GH deficiency (Table 2). A decrease must, therefore, be considered in relation to other clinical factors when making a diagnosis for an individual patient. Both IGF-I and IGFBP-3 can help distinguish short stature due to GH deficiency from other conditions. In patients younger than 8 years of age, IGF-I levels are relatively low, making it difficult to discriminate between normal and subnormal values. In these young patients IGFBP-3 may provide a better indicator of $\mathrm{GH}$ deficiency than IGF-I SDS (61).

\section{The IGF-I generation test}

The IGFGT was designed in the 1980s to predict growth responses to $\mathrm{GH}$ in patients with $\mathrm{GH}$ deficiency. At the time however, this was considered unsatisfactory, the test was abandoned and normative data were not established. Interest in the IGFGT was renewed when patients with short stature associated with GH resistance were selected for recombinant human IGF-I therapy. As the spectrum of short stature disorders grew over time, with many associated with some degree of $\mathrm{GH}$ resistance, the criteria of absent responses of IGF-I and IGFBP-3 became too strict for paediatric patients with mild GH resistance or idiopathic short stature (70). Attempts to refine the IGFGT for investigation of growth failure demonstrated that subnormal IGF-I responses were seen in patients with idiopathic short stature; however, additional sensitivity for the diagnosis of GH resistance was not seen with a lowdose GH protocol (71). For these reasons, the IGFGT is not recommended in the routine investigation of short stature (70), although it may support the decision regarding IGF-I treatment in patients with severe $\mathrm{GH}$ resistance.

\section{IGF-I and IGFBP-3 in GH deficiency}

While IGF-I and IGFBP-3 concentrations are only an aid to identify GH deficiency, they do indicate whether a particular $\mathrm{GH}$ deficient patient will benefit from $\mathrm{GH}$ therapy. The gain in height velocity during GH treatment is significantly correlated with the pre-treatment IGF-I and IGFBP-3 levels. Patients with the lowest levels will generally have a better response to treatment (72).

GH deficiency can be due to many causes and the response to treatment differs according to the aetiology. For approximately $80 \%$ of patients the cause is not specifically identified and is reported as idiopathic GH deficiency (41). Structural defects are most commonly associated with pituitary abnormalities, which can be identified by magnetic resonance imaging $(73,74)$. Such patients have very low serum IGF-I SDS and the level depends on the severity of the condition. Acquired GH deficiency occurs less frequently, accounting for approximately $20 \%$ of cases. It may result from brain tumours following radiotherapy affecting the central nervous system.

\section{IGF-I and IGFBP-3 in non-GH deficient short stature}

IGF-I SDS and IGFBP-3 SDS below -2 would indicate an abnormality in the $\mathrm{GH}$ axis, provided that other factors, such as malnutrition, severe illness and trauma, have been eliminated. In patients with non-GH-deficient short stature, IGF-I SDS and IGFBP-3 SDS values generally do not contribute to the diagnosis. In patients with idiopathic short stature, without evident GH deficiency and no other

Table 2 Clinical conditions with decreased IGF-I concentration.

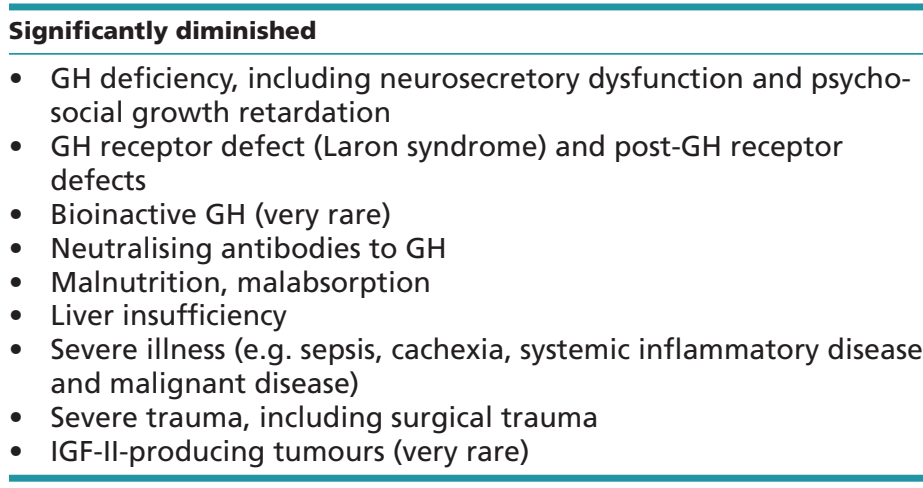

\section{Moderately diminished}

- GH deficiency in the presence of severe obesity (e.g. Prader-Willi syndrome)

- GH deficiency after treatment for malignancy

- Diabetes mellitus

- Hypothyroidism

- GH insufficiency

- Constitutional delay of growth and adolescence (normal IGFBP-3)

- Sex steroid deficiency (e.g. Turner syndrome at the age of puberty)

GH, growth hormone; IGF, insulin-like growth factor; IGFBP, IGF-binding protein.

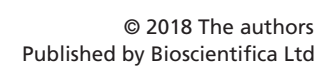

Published by Bioscientifica Ltd http://www.endocrineconnections.org https://doi.org/10.1530/EC-18-0099

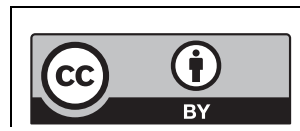

This work is licensed under a Creative Commons Attribution 4.0 International License. 
cause identified, approximately 40\% may have IGF-I SDS below the normal range (61). Patients with other causes of short stature, such as Turner syndrome, born SGA without catch-up growth and abnormalities of the short stature homeobox-containing gene (SHOX), generally have IGF-I SDS within the normal range. However during GH therapy in Turner syndrome and SGA, IGF-I SDS values of $>2$ may be seen and require monitoring. Prolonged elevation of IGF-I may indicate the need to decrease the dose of GH.

The combination of short stature and IGF-I levels close to or above the upper limit of the normal range should trigger particular attention to the phenotype and a possible history of low birth weight. IGF-I receptor defects combine low birth weight and high normal IGF-I values (1). The recently reported mutations of the proteolytic factor PAPP-A2 are associated with a short stature phenotype which may be subtle, but includes facial and skeletal dysmorphism and IGF-I, IGFBP-3 and ALS values that are pathologically elevated (75).

\section{IGF-I and IGFBP-3 measurements during GH therapy}

\section{Use of IGF-I and IGFBP-3 for initiation and evaluation}

During GH therapy in patients with short stature, monitoring of IGF-I SDS and IGFBP-3 SDS can be used for testing compliance and guiding GH dose adjustments. Evaluation of safety is also an important role for IGF-I monitoring, with the aim being to avoid increases above the normal range. IGF-I levels at baseline and changes during GH therapy are used in prediction models of the growth response to GH therapy $(6,72)$. After starting $\mathrm{GH}$ therapy, IGF-I takes 3 to 5 days to increase sufficiently for monitoring of responsiveness (76). Restoration of IGF-I SDS within the normal range has been suggested when monitoring effectiveness of GH therapy in children. However, for children with GH deficiency, GH therapy is effective even when IGF-I SDS is not normalised, particularly in patients with severe GH deficiency when pre-treatment IGF-I SDS is very low (77).

\section{Epidemiological studies of high IGF-I and IGFBP-3}

Epidemiological studies in adults have suggested that high IGF-I concentrations could potentially be associated with certain cancers; however, opposite effects have been reported for high IGFBP-3. Hypothetically, assessment of possible risk can be identified using tertiles of IGF-I SDS and IGFBP-3 SDS. Patients with levels in the possible risk area of high IGF-I SDS with concomitant low IGFBP-3 SDS may require a reduction in $\mathrm{GH}$ dose in order to avoid any potential risk of adverse events (61).

\section{Conclusions}

In the healthy child, the GH-IGF-I axis drives the mechanisms of anabolism and linear growth. Physiologically, IGF-I provides the message to cells that nutrition and general health are appropriate for enhanced protein synthesis, increased mitosis and avoidance of apoptosis in response to stimuli. Each process is regulated by GH, IGF-I and IGFBP-3, together with insulin, in the appropriate target tissue. Assessment of GH secretory capacity is a key stage in the investigation of short stature and is generally recommended, except in the child with normal serum IGF-I and normal height velocity. The use of measurements of serum IGF-I and IGFBP-3 concentrations is also recommended, but has been hindered by assay difficulties. In GH deficiency, low IGF-I and IGFBP-3 levels complement the finding of diminished peak $\mathrm{GH}$ in response to provocative testing. IGF-I and IGFBP-3 measurements can inform the clinician about adherence to GH treatment and, if maintained at $<+2$ SDS, will generally avoid GH over-dosage.

As explained above, multiple factors can influence serum IGF-I and IGFBP-3 concentrations, hence they are not the pure guide to $\mathrm{GH}$ secretion or action. Nevertheless, they are valuable investigative and therapeutic tools which contribute to the variables available to clinicians for the management of growth failure in children.

\section{Declaration of interest}

$\mathrm{E} \mathrm{K}$ is an employee of Merck KGaA, Germany. The remaining authors declare that there is no conflict of interest that could be perceived as prejudicing the impartiality of this review.

\section{Funding}

This work was supported by Merck Serono Middle East FZ-LLC, Dubai, UAE, an affiliate of Merck KGaA, Darmstadt, Germany.

\section{Acknowledgements}

The authors acknowledge the contributions of the paediatric endocrinologists who attended the Advisory Board, ELITE II, organised by Akram Kharbat, Ayman Haridy and Ekaterina Koledova of Merck KGaA, Darmstadt, held in Dubai, UAE, in December 2016. The contributing specialists were: Abdullah Alherbish, Afaf Alsagheir, Bassam Bin Abbass,

This work is licensed under a Creative Commons Attribution 4.0 International License. 
Angham Almutair, Mohammed al Qahtani, Walid Kaplan, Ahmed El Awwa, Iman al Basiri, Zaidan al Mazeedy. We also acknowledge the medical writing skills of Dr Peter Bates, Cambridge Medical Writing Services, UK.

\section{References}

1 David A, Hwa V, Metherell LA, Netchine I, Camacho-Hübner C, Clark AJ, Rosenfeld RG \& Savage MO. Evidence for a continuum of genetic, phenotypic, and biochemical abnormalities in children with growth hormone insensitivity. Endocrine Reviews 201132 472-497. (https://doi.org/10.1210/er.2010-0023)

2 Bang P, Bjerknes R, Dahlgren J, Dunkel L, Gustafsson J, Juul A, Kriström B, Tapanainen P \& Aberg V. A comparison of different definitions of growth response in short prepubertal children treated with growth hormone. Hormone Research in Paediatrics 201175 335-345. (https://doi.org/10.1159/000322878)

3 Sprogøe K, Mortensen E, Karpf DB \& Leff JA. The rationale and design of TransCon Growth Hormone for the treatment of growth hormone deficiency. Endocrine Connections 20176 R171-R181. (https://doi.org/10.1530/EC-17-0203)

4 Høybye C, Cohen P, Hoffman AR, Ross R, Biller BM, Christiansen JS $\&$ Growth Hormone Research Society. Status of long-acting-growth hormone preparations - 2015. Growth Hormone and IGF Research 2015 25 201-206. (https://doi.org/10.1016/j.ghir.2015.07.004)

5 Savage MO, Burren CP \& Rosenfeld RG. The continuum of growth hormone-IGF-I axis defects causing short stature: diagnostic and therapeutic challenges. Clinical Endocrinology 201072 721-728. (https://doi.org/10.1111/j.1365-2265.2009.03775.x)

6 Wit JM, Ranke MB, Albertsson-Wikland K, Carrascosa A, Rosenfeld RG, Van Buuren S, Kristrom B, Schoenau E, Audi L, Hokken-Koelega AC, et al. Personalized approach to growth hormone treatment: clinical use of growth prediction models. Hormone Research in Paediatrics 201379 257-270. (https://doi. org/10.1159/000351025)

7 Albertsson-Wikland K, Rosberg S, Karlberg J \& Groth T. Analysis of 24-hour growth hormone profiles in healthy boys and girls of normal stature: relation to puberty. Journal of Clinical Endocrinology and Metabolism 199478 1195-1201. (https://doi.org/10.1210/ jcem.78.5.8175978)

8 Le Roith D, Bondy C, Yakar S, Liu JL \& Butler A. The somatomedin hypothesis: 2001. Endocrine Reviews 200122 53-74. (https://doi. org/10.1210/edrv.22.1.0419)

9 Baron J, Sävendahl L, De Luca F, Dauber A, Phillip M, Wit JM \& Nilsson O. Short and tall stature: a new paradigm emerges. Nature Reviews: Endocrinology 201511 735-746. (https://doi.org/10.1038/ nrendo.2015.165)

10 Brissenden JE, Ullrich A \& Francke U. Human chromosomal mapping of genes for insulin-like growth factors I and II and epidermal growth factor. Nature 1984310 781-784. (https://doi.org/10.1038/310781a0)

11 Hwa V, Oh Y \& Rosenfeld RG. The insulin-like growth factor-binding protein (IGFBP) superfamily. Endocrine Reviews 199920 761-787. (https://doi.org/10.1210/edrv.20.6.0382)

12 Ranke MB. Insulin-like growth factor binding-protein-3 (IGFBP-3). Best Practice and Research Clinical Endocrinology and Metabolism 2015 29 701-711. (https://doi.org/10.1016/j.beem.2015.06.003)

13 Johnson MA \& Firth SM. IGFBP-3: a cell fate pivot in cancer and disease. Growth Hormone and IGF Research 201424 164-173. (https:// doi.org/10.1016/j.ghir.2014.04.007)

14 Weber MM, Auernhammer CJ, Lee PD, Engelhardt D \& Zachoval R. Insulin-like growth factors and insulin-like growth factor binding proteins in adult patients with severe liver disease before and after orthotopic liver transplantation. Hormone Research 200257 105-112. (https://doi.org/10.1159/000057960)

15 Leung KC, Doyle N, Ballesteros M, Waters MJ \& Ho KK. Insulin regulation of human hepatic growth hormone receptors: divergent effects on biosynthesis and surface translocation. Journal of Clinical Endocrinology and Metabolism 200085 4712-4720. (https://doi. org/10.1210/jcem.85.12.7017)

16 Purandare A, Co Ng L, Godil M, Ahnn SH \& Wilson TA. Effect of hypothyroidism and its treatment on the IGF system in infants and children. Journal of Pediatric Endocrinology and Metabolism 200316 35-42. (https://doi.org/10.1515/jpem.2003.16.1.35)

17 Meinhardt UJ \& Ho KK. Modulation of growth hormone action by sex steroids. Clinical Endocrinology 200665 413-422. (https://doi. org/10.1111/j.1365-2265.2006.02676.x)

18 Hawkes CP \& Grimberg A. Insulin-like growth factor-I is a marker for the nutritional state. Pediatric Endocrinology Reviews 201513 499-511.

19 Jansson UH, Kristiansson B, Magnusson P, Larsson L, AlbertssonWikland K \& Bjarnason R. The decrease of IGF-I, IGF-binding protein-3 and bone alkaline phosphatase isoforms during gluten challenge correlates with small intestinal inflammation in children with coeliac disease. European Journal of Endocrinology 2001144 417-423. (https://doi.org/10.1530/eje.0.1440417)

20 Støving RK, Hangaard J, Hagen C \& Flyvbjerg A. Low levels of the $150-\mathrm{kD}$ insulin-like growth factor binding protein 3 ternary complex in patients with anorexia nervosa: effect of partial weight recovery. Hormone Research 200360 43-48. (https://doi. org/10.1159/000070826)

21 Fazeli PK \& Klibanski A. Determinants of GH resistance in malnutrition. Journal of Endocrinology 2014220 R57-R65. (https:// doi.org/10.1530/JOE-13-0477)

22 Zhao Y, Xiao Z, Frank SJ, Lin HY \& Xia Y. Distinct mechanisms of induction of hepatic growth hormone resistance by endogenous IL-6, TNF- $\alpha$, and IL-1ß. American Journal of Physiology: Endocrinology and Metabolism 2014307 E186-E198. (https://doi.org/10.1152/ ajpendo.00652.2013)

23 Choukair D, Hügel U, Sander A, Uhlmann L \& Tönshoff B. Inhibition of IGF-I-related intracellular signaling pathways by proinflammatory cytokines in growth plate chondrocytes. Pediatric Research 201476 245-251. (https://doi.org/10.1038/pr.2014.84)

24 Salmon WD Jr \& Daughaday WH. A hormonally controlled serum factor which stimulates sulfate incorporation by cartilage in vitro. Journal of Laboratory and Clinical Medicine 195749 825-436.

25 Green H, Morikawa M \& Nixon T. A dual effector theory of growthhormone action. Differentiation 198529 195-198. (https://doi. org/10.1111/j.1432-0436.1985.tb00316.x)

26 Nilsonn O, Marino R, De Luca F, Phillip M \& Baron J. Endocrine regulation of the growth plate. Hormone Research 200564 157-165. (https://doi.org/10.1159/000088791)

27 Isaksson OG, Lindahl A, Nilsson A \& Isgaard J. Mechanism of the stimulatory effect of growth hormone on longitudinal bone growth. Endocrine Reviews 19878 426-438. (https://doi.org/10.1210/edrv-8-4426)

28 Wang J, Zhou J, Cheng CM, Kopchick JJ \& Bondy CA. Evidence supporting dual, IGF-I-independent and IGF-I-dependent, role for GH in promoting longitudinal bone growth. Journal of Endocrinology 2004180 247-255. (https://doi.org/10.1677/joe.0.1800247)

29 Mehta A, Hindmarsh PC, Stanhope RG, Turton JP, Cole TJ, Preece MA \& Dattani MT. The role of growth hormone in determining birth size and early postnatal growth, using congenital growth hormone deficiency (GHD) as a model. Clinical Endocrinology 200563 223-231. (https://doi.org/10.1111/j.13652265.2005.02330.x)

30 Netchine I, Azzi S, Le Bouc Y \& Savage MO. IGF1 molecular anomalies demonstrate its critical role in fetal, postnatal growth and brain development. Best Practice and Research Clinical Endocrinology and Metabolism 201125 181-190. (https://doi.org/10.1016/j. beem.2010.08.00)

31 Klammt J, Kiess W and Pfäffle R. IGF1R mutations as cause of SGA. Best Practice and Research Clinical Endocrinology and Metabolism 2011 25 191-206. (https://doi.org/10.1016/j.beem.2010.09.012)

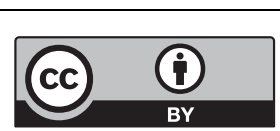

This work is licensed under a Creative Commons Attribution 4.0 International License. 
32 Yakar S, Rosen CJ, Beamer WG, Ackert-Bicknell CL, Wu Y, Liu JL, Ooi GT, Setser J, Frystyk J, Boisclair YR, et al. Circulating levels of IGF-1 directly regulate bone growth and density. Journal of Clinical Investigation 2002110 771-781. (https://doi.org/10.1172/ JCI200215463)

33 Domené HM, Hwa V, Jasper HG \& Rosenfeld RG. Acid-labile subunit (ALS) deficiency. Best Practice and Research Clinical Endocrinology and Metabolism 201125 101-113. (https://doi.org/10.1016/j. beem.2010.08.010)

34 Storr HL, Prasad R, Temple IK, Metherell LA, Savage MO \& Walker JM. Heterogeneity of the growth phenotype and birth size in acid-labile subunit (ALS) deficiency. Journal of Endocrinological Investigation 201538 407-412. (https://doi.org/10.1007/s40618-0140195-1)

35 Işık E, Haliloglu B, van Doorn J, Demirbilek H, Scheltinga SA, Losekoot M \& Wit JM. Clinical and biochemical characteristics and bone mineral density of homozygous, compound heterozygous and heterozygous carriers of three novel IGFALS mutations. European Journal of Endocrinology 2017176 657-667. (https://doi.org/10.1530/ EJE-16-0999)

36 Courtland HW, Sun H, Beth-On M, Wu Y, Elis S, Rosen CJ \& Yakar S. Growth hormone mediates pubertal skeletal development independent of hepatic IGF-1 production. Journal of Bone and Mineral Research 201126 761-768. (https://doi.org/10.1002/jbmr.265)

37 Grimberg A, DiVall SA, Polychronakos C, Allen DB, Cohen LE, Quintos JB, Rossi WC, Feudtner C, Murad MH \& Drug and Therapeutics Committee and Ethics Committee of the Pediatric Endocrine Society. Guidelines for growth hormone and insulinlike growth factor-I treatment in children and adolescents: growth hormone deficiency, idiopathic short stature, and primary insulinlike growth factor-I deficiency. Hormone Research in Pediatrics 201686 361-397. (https://doi.org/10.1159/000452150)

38 Savage MO, Backeljauw PF, Calzada R, Cianfarani S, Dunkel L \& Koledova E,. Early detection, referral, investigation, and diagnosis of children with growth disorders. Hormone Research in Pediatrics 2016 85 325-332. (https://doi.org/10.1159/000444525)

39 Rogol AD \& Hayden GF. Etiologies and early diagnosis of short stature and growth failure in children and adolescents. Journal of Pediatrics 2014164 S1-S14. (https://doi.org/10.1016/j. jpeds.2014.02.027)

40 Oostdijk W, Grote FK, de Muinck Keizer-Schrama SM \& Wit JM. Diagnostic approach in children with short stature. Hormone Research 200972 206-217. (https://doi.org/10.1159/000236082)

41 Cohen P, Rogol AD, Deal CL, Saenger P, Reiter EO, Ross JL, Chernausek SD, Savage MO, Wit JM \& on behalf of the 2007 ISS Consensus Workshop participants. Consensus statement on the diagnosis and treatment of children with idiopathic short stature: a summary of the Growth Hormone Research Society, the Lawson Wilkins Pediatric Endocrine Society, and the European Society for Paediatric Endocrinology Workshop. Journal of Clinical Endocrinology and Metabolism 200893 4210-4217. (https://doi.org/10.1210/jc.2008-0509)

42 Growth Hormone Research Society. Consensus guidelines for the diagnosis and treatment of growth hormone (GH) deficiency in childhood and adolescence: summary statement of the GH Research Society. GH Research Society. Journal of Clinical Endocrinology and Metabolism 200085 3990-3993. (https://doi.org/10.1210/ jcem.85.11.6984)

43 WHO Multicentre Growth Reference Study Group. WHO Child Growth Standards based on length/height, weight and age. Acta Paediatrica Supplement 2006450 76-85. (https://doi. org/10.1080/08035320500495548)

44 Saari A, Sankilampi U \& Dunkel L. Multiethnic WHO growth charts may not be optimal in the screening of disorders affecting height: Turner syndrome as a model. JAMA Pediatrics 2013167 194-195. (https://doi.org/10.1001/jamapediatrics.2013.436
45 Argente J. Challenges in the management of short stature. Hormone Research in Paediatrics 201685 2-10. (https://doi. org/10.1159/000442350)

46 Sisley S, Trujillo MV, Khoury J \& Backeljauw P. Low incidence of pathology detection and high cost of screening in the evaluation of asymptomatic short children. Journal of Pediatrics 2013163 1045-1051. (https://doi.org/10.1016/j.jpeds.2013.04.002)

47 Bhadada SK, Bhansali A, Kochhar R, Menon AS, Sinha SK, Dutta P $\&$ Nain CK. Does every short stature child need screening for celiac disease? Journal of Gastroenterology and Hepatology 200823 e353-e356. (https://doi.org/10.1111/j.1440-1746.2007.05261.x)

48 Saari A, Harju S, Mäkitie O, Saha MT, Dunkel L \& Sankilampi U. Systematic growth monitoring for the early detection of celiac disease in children. JAMA Pediatrics 2015169 e1525. (https://doi. org/10.1001/jamapediatrics.2015.25)

49 Ley D, Duhamel A, Behal H, Vasseur F, Sarter H, Michaud L, GowerRousseau C \& Turck D. Growth pattern in paediatric Crohn disease is related to inflammatory status. Journal of Pediatric Gastroenterology and Nutrition 201663 637-643. (https://doi.org/10.1097/ MPG.0000000000001177)

50 Stochholm K, Juul S, Juel K, Naeraa RW \& Gravholt CH. Prevalence, incidence, diagnostic delay, and mortality in Turner syndrome. Journal of Clinical Endocrinology and Metabolism 200691 3897-3902. (https://doi.org/10.1210/jc.2006-0558)

51 Davenport ML, Crowe BJ, Travers SH, Rubin K, Ross JL, Fechner PY, Gunther DF, Liu C, Geffner ME, Thrailkill K, et al. Growth hormone treatment of early growth failure in toddlers with Turner syndrome: a randomized, controlled, multicenter trial. Journal of Clinical Endocrinology and Metabolism 200792 3406-3416. (https://doi. org/10.1210/jc.2006-2874)

52 Ranke MB \& Lindberg A. Predicting growth in response to growth hormone treatment. Growth Hormone and IGF Research 200919 1-11. (https://doi.org/10.1016/j.ghir.2008.08.001)

53 Marchini A, Ogata T \& Rappold GA. A track record on SHOX: from basic research to complex models and therapy. Endocrine Reviews 201637 417-448. (https://doi.org/10.1210/er.2016-1036)

54 Maghnie M, Labarta JI, Koledova E \& Rohrer TR. Short stature diagnosis and referral. Frontiers in Endocrinology 20188374 (https:// doi.org/10.3389/fendo2017.00374)

55 Clemmons DR. Consensus statement on the standardization and evaluation of growth hormone and insulin-like growth factor assays. Clinical Chemistry 201157 555-559. (https://doi.org/10.1373/ clinchem.2010.150631)

56 Juul A, Bernasconi S, Clayton PE, Kiess W, DeMuinck-Keizer Schrama S \& Drugs and Therapeutics Committee of the European Society for Paediatric Endocrinology (ESPE). European audit of current practice in diagnosis and treatment of childhood growth hormone deficiency. Hormone Research 200258 233-241. (1doi:0.1159/000066265) (https://doi.org/10.1159/000066265)

57 Secco A, di Iorgi N, Napoli F, Calandra E, Ghezzi M, Frassinetti C, Parodi S, Casini MR, Lorini R, Loche S, et al. The glucagon test in the diagnosis of growth hormone deficiency in children with short stature younger than 6 years. Journal of Clinical Endocrinology and Metabolism 200994 4251-4257. (https://doi.org/10.1210/jc.20090779)

58 Stanley TL, Levitsky LL, Grinspoon SK \& Misra M. Effect of body mass index on peak growth hormone response to provocative testing in children with short stature. Journal of Clinical Endocrinology and Metabolism 200994 4875-4881. (https://doi.org/10.1210/jc.20091369)

59 Frystyk J, Freda P \& Clemmons DR. The current status of IGF-I assays - a 2009 update. Growth Hormone and IGF Research 201020 8-18. (https://doi.org/10.1016/j.ghir.2009.09.00)

60 Hjortebjerg R \& Frystyk J. Determination of IGFs and their binding proteins. Best Practice and Research Clinical Endocrinology http://www.endocrineconnections.org

https://doi.org/10.1530/EC-18-0099 (c) 2018 The authors

Published by Bioscientifica Ltd

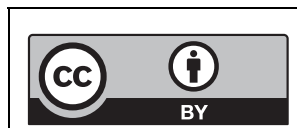

This work is licensed under a Creative Commons Attribution 4.0 International License. 
and Metabolism 201327 771-781. (https://doi.org/10.1016/j. beem.2013.08.010)

61 Blum WF, Böttcher C \& Wudy SA. Insulin-like growth factors and their binding proteins. In Diagnostics of Endocrine Function in Children and Adolescents, 4th ed., pp 157-182. Eds MB Ranke \& P-E Mullis. Basel: Karger, 2011.

62 Blum WF, Ranke MB \& Bierich JR. A specific radioimmunoassay for insulin-like growth factor II: the interference of IGF binding proteins can be blocked by excess IGF-I. Acta Endocrinologica 1988118 374-80. (https://doi.org/10.1530/acta.0.1180374)

63 Blum WF \& Breier BH. Radioimmunoassays for IGFs and IGFBPs. Growth Regulation 19944 (Supplement 1) 11-19.

64 Blum WF, Ranke MB, Kietzmann K, Gauggel E, Zeisel HJ \& Bierich JR. A specific radioimmunoassay for the growth hormone $(\mathrm{GH})$ dependent somatomedin-binding protein: its use for diagnosis of $\mathrm{GH}$ deficiency. Journal of Clinical Endocrinology and Metabolism 199070 1292-1298. (https://doi.org/10.1210/jcem-70-5-1292)

65 Löfqvist C, Andersson E, Gelander L, Rosberg S, Hulthen L, Blum WF $\&$ Wikland KA. Reference values for insulin-like growth factorbinding protein-3 (IGFBP-3) and the ratio of insulin-like growth factor-I to IGFBP-3 throughout childhood and adolescence. Journal of Clinical Endocrinology and Metabolism 200590 1420-1427. (https:// doi.org/10.1210/jc.2004-0812)

66 Chanson P, Arnoux A, Mavromati M, Brailly-Tabard S, Massart C, Young J, Piketty ML, Souberbielle JC \& VARIETE Investigators. Reference values for IGF-I serum concentrations: comparison of six immunoassays. Journal of Clinical Endocrinology and Metabolism 2016 101 3450-3458. (https://doi.org/10.1210/jc.2016-1257)

67 Boettcher C, Schaeffer M, Wudy SA \& Blum WF. Cross-calibration of IGF-I and IGFBP-3 assays to obtain comparable values. Hormone Research in Paediatrics 200665 (Supplement 4) 178. (https://doi. org/10.1159/000094504)

68 Bidlingmaier M, Friedrich N, Emeny RT, Spranger J, Wolthers OD, Roswall J, Körner A, Obermayer-Pietsch B, Hübener C, Dahlgren J, et al. Reference intervals for insulin-like growth factor-1 (IGF-I) from birth to senescence: results from a multicenter study using a new automated chemiluminescence IGF-I immunoassay conforming to recent international recommendations. Journal of Clinical Endocrinology and Metabolism 201499 1712-1721. (https://doi. org/10.1210/jc.2013-3059)

69 Friedrich N, Wolthers OD, Arafat AM, Emeny RT, Spranger J, Roswall J, Kratzsch J, Grabe HJ, Hübener C, Pfeiffer AF, et al. Age- and sex-specific reference intervals across life span for insulin-like growth factor binding protein 3 (IGFBP-3) and the IGF-I to IGFBP-3 ratio measured by new automated chemiluminescence assays. Journal of Clinical Endocrinology and Metabolism 201499 1675-1686. (https:// doi.org/10.1210/jc.2013-3060)

70 Coutant R, Dörr HG, Gleeson H \& Argente J. Diagnosis of endocrine disease: limitations of the IGF1 generation test in children with short stature. European Journal of Endocrinology 2012166 351-357. (https:// doi.org/10.1530/EJE-11-0618)

71 Buckway CK, Guevara-Aguirre J, Pratt KL, Burren CP \& Rosenfeld RG. The IGF-I generation test revisited: a marker of GH sensitivity. Journal of Clinical Endocrinology and Metabolism 200186 5176-5183. (https:// doi.org/10.1210/jcem.86.11.8019)

72 Schönau E, Westermann F, Rauch F, Stabrey A, Wassmer G, Keller E, Brämswig J, Blum WF \& The German Lilly Growth Response Study Group. A new and accurate prediction model for growth response to growth hormone treatment in children with growth hormone deficiency. European Journal of Endocrinology 2001144 13-20. (https:// doi.org/10.1530/eje.0.1440013)

73 Maghnie M, Lindberg A, Koltowska-Häggström M \& Ranke MB. Magnetic resonance imaging of CNS in 15,043 children with GH deficiency in KIGS (Pfizer International Growth Database). European Journal of Endocrinology 2013168 211-217. (https://doi.org/10.1530/ EJE-12-0801)

74 Deal C, Hasselmann C, Pfäffle RW, Zimmermann AG, Quigley CA, Child CJ, Shavrikova EP, Cutler GB \& Blum WF. Associations between pituitary imaging abnormalities and clinical and biochemical phenotypes in children with congenital growth hormone deficiency: data from an international observational study. Hormone Research in Paediatrics 201379 283-292. (https://doi. org/10.1159/000350829)

75 Dauber A, Muñoz-Calvo MT, Barrios V, Domené HM, Kloverpris S, Serra-Juhé C, Desikan V, Pozo J, Muzumdar R, Martos-Moreno GÁ, et al. Mutations in pregnancy-associated plasma protein A2 cause short stature due to low IGF-I availability. EMBO Molecular Medicine 20168 363-374. (https://doi.org/10.15252/emmm.201506106)

76 Blair JC, Camacho-Hübner C, Miraki Moud F, Rosberg S, Burren C, Lim S, Clayton PE, Bjarnason R, Albertsson-Wikland K \& Savage MO. Standard and low-dose IGF-I generation tests and spontaneous growth hormone secretion in children with idiopathic short stature. Clinical Endocrinology 200460 163-168. (10.1111/j.13652265.2003.01957.x)

77 Blum WF, Shavrikova EP \& Crowe BJ. The growth response to GH treatment in children with GH deficiency is not different between those who do or do not normalize their IGF-I levels. Growth Hormone and IGF Research 200616 (Supplement B) 35.

Received in final form 25 April 2018

Accepted 3 May 2018

Accepted Preprint published online 3 May 2018 http://www.endocrineconnections.org https://doi.org/10.1530/EC-18-0099 (c) 2018 The authors Published by Bioscientifica Ltd

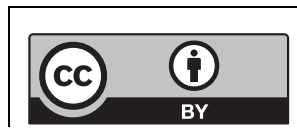

This work is licensed under a Creative Commons Attribution 4.0 International License. 